\title{
Immunoglobulin G Independent Activation of the Classical Complement Pathway by Monosodium
} Urate Crystals

\author{
Patricia C. Giclas, Mark H. Ginsberg, and Neil R. Cooper, Department of \\ Pediatrics, National Jewish Hospital, Denver, Colorado 80206; Departments of \\ Immunopathology and Molecular Immunology Research Institute of Scripps \\ Clinic, La Jolla, California 92037
}

A B S T R A C T $10 \mathrm{mg}$ of monosodium urate crystals reduced the $\mathrm{CH}_{50}$ of $1 \mathrm{ml}$ of human serum by $57 \%$ after $30 \mathrm{~min}$ at $37^{\circ} \mathrm{C}$. C1, C4, and C3 depletion of 52,68 , and $46 \%$ were typical of classical pathway activation. $\mathrm{Cl}$ binding and activation occurred when urate crystals were incubated with isolated precursor $\mathrm{Cl}$, and required the intact macromolecule, Clqrs. Activation of isolated $\mathrm{Cl}$ by urate crystals was not diminished by $\mathrm{F}\left(\mathrm{ab}^{\prime}\right)_{2}$ anti-Fc under conditions in which $\mathrm{Cl}$ activation by aggregated immunoglobulin $(\mathrm{G})$ was blocked by the $\mathrm{F}\left(\mathrm{ab}^{\prime}\right)_{2}$ antibody.

\section{INTRODUCTION}

Monosodium urate crystals initiate gouty inflammation. Several lines of evidence have implicated the complement system in this process. For example, prior complement depletion in rats (1) and dogs (2) ameliorates the inflammation of experimentally induced gout. Further, urate crystals activate complement in human serum (3) with concomitant development of mediators of inflammation (4). Thus, activation of complement by monosodium urate crystals may well contribute to the development of acute gout.

The mechanism by which complement is activated by urate crystals has not been fully elucidated. Naff and Byers (3) reported that serum incubated with crystals showed depleted levels of complement

This is publication 1528 from the Department of Immunology and Pathology, Research Institute of Scripps Clinic, La Jolla, Calif.

Dr. Giclas is a recipient of National Institutes of Health Research Fellowship Award 5-F32-AI05739-02. Dr. Ginsberg is a recipient of U. S. Public Health Service Clinical Investigator Award 1KO8-AM 00393-1.

Received for publication 22 September 1978 and in revised form 8 December 1978. components, C2 to C5. These workers suggested that urates activate complement via a novel pathway, because $\mathrm{Cl}$ was only slightly depleted. One purpose of this study was to determine a mechanism by which the components of the classical complement pathway might be activated by urate crystals.

It is known that urate crystals avidly bind immunoglobulin $(G)$ when exposed to serum (5). This suggests the possibility that adsorbed immunoglobulin might be responsible for activation of complement by urate crystals in serum. Although Naff and Byers (3) reported that urate crystals also activated complement in immunoglobulin-deficient sera, the presence of minor quantities of contaminating immunoglobulin could not be excluded. The purpose of this study was thus twofold. First, we wanted to determine to what extent urate crystals could activate $\mathrm{Cl}$, either in serum or in purified form, and second, whether IgG might be required for the observed $\mathrm{Cl}$ activation.

\section{METHODS}

Urate crystals. Uric acid crystals (ICN Pharmaceuticals Inc., Cleveland, Ohio) were heated at $200^{\circ} \mathrm{C}$ for $2 \mathrm{~h}$ to destroy possible pyrogens. These crystals were then slowly neutralized under aseptic conditions with $0.1 \mathrm{M} \mathrm{NaOH}$ in sterile nonpyrogenic water in glassware that had been heated $200^{\circ} \mathrm{C}$ for $2 \mathrm{~h}$ as described (6). The monosodium urate crystals produced were negatively birefringent needleshaped, and showed an x-ray powder diffraction pattern typical of monosodium urate monohydrate (7). Culture of the crystal suspension yielded no bacterial growth. Crystals were stored at $-20^{\circ} \mathrm{C}$ at $25 \mathrm{mg} / \mathrm{ml}$, and thawed once before use.

Reagents and proteins. Sodium dodecyl sulfate (SDS), ${ }^{1}$ acrylamide, and dithiothreitol were purchased from Sigma

\footnotetext{
${ }^{1}$ Abbreviations used in this paper: SDG, sucrose density gradient; SDS, sodium dodecyl sulfate; SDS-PAGE, SDS polyacrylamide gel electrophoresis.
} 
Chemical Co. (St. Louis, Mo.) and Bio-Rad Laboratories (Richmond, Calif.). Precursor forms of Clq, Clr, and Cls were purified from normal human serum by published methods $(8-10)$. Human immunoglobulin (IgG) was prepared by DEAE cellulose chromatography of dialyzed human serum $(0.01 \mathrm{M}$ phosphate buffer, $\mathrm{pH} 7.4)$ and was heat aggregated at $63^{\circ} \mathrm{C}$ for $15 \mathrm{~min}$. Cls was radiolabeled with $\mathrm{Na}{ }^{125}$ I (carrier free, New England Nuclear, Boston, Mass.) using lactoperoxidase-coupled Sepharose beads (Pharmacia Fine Chemicals, Piscataway, N. J.) as described (11). $\mathrm{F}\left(\mathrm{ab}^{\prime}\right)_{2}$ fragments of goat anti-human $\mathrm{Fc}_{\mathrm{c}}$ antibody were prepared as published (12).

Reconstitution of macromolecular proenzyme Cl. $\mathrm{Cl}$ was reconstituted from highly purified $\mathrm{Clq}$, proenzyme $\mathrm{Clr}$, and ${ }^{125}$ I-labeled proenzyme $\mathrm{Cls}$ in the presence of calcium as described (11).

SDS polyacrylamide gel electrophoresis (SDS-PAGE). Experiments were performed with a modification (9) of the method of Weber and Osborn (13). After electrophoresis, gels were sectioned at $2-\mathrm{mm}$ intervals and analyzed for radioactivity.

Sucrose density gradient (SDG) ultracentrifugation. SDG studies were carried out in $9-31 \%$ linear sucrose gradients in barbital-buffered saline containing $1.5 \times 0.1 \mathrm{mM}$ calcium chloride (14) exactly as published (15).

Complement and complement component measurements. Complement and C1, C3 (16), and C4 (17) measurements were carried out by standard hemolytic techniques.

C1 binding assays. Binding of $\mathrm{Cl}$ to urate crystals was assessed directly, with SDG ultracentrifugation. This technique was chosen because it permits not only direct measurement of $\mathrm{Cl}$ binding but also detects $\mathrm{Cl}$ that has been activated and has dissociated from the activator (18). Varying amounts of urate crystals in $5 \mu \mathrm{l}$ vol were incubated for $10 \mathrm{~min}$ at $0^{\circ} \mathrm{C}$ with $8 \mu \mathrm{g}$ of $\mathrm{Clq}$ and $4 \mu \mathrm{g}$ each of $\mathrm{Clr}$ and ${ }^{125} \mathrm{I}-\mathrm{Cls}$ in a total volume of $20-30 \mu \mathrm{l}$ in $0.05 \mathrm{M}$ Tris, pH 7.5 containing $0.1 \mathrm{M} \mathrm{NaCl}$ and $0.005 \mathrm{M}$ calcium resulting in the formation of $5 \mu \mathrm{g} \mathrm{Cl}$ macromolecule plus remaining free subcomponents. The mixtures were then subjected to SDG as described above. The proportion of radioactivity in the $16 \mathrm{~S}$ peak and on the bottom of the tubes was taken as total $\mathrm{Cl}$ for calculating the percentage bound (bottom) in the control and experimental samples.

C1 activation assays. Determination of $\mathrm{Cl}$ activation was carried out by procedures that have been published (11). In brief, reconstituted $\mathrm{Cl}$ was further purified by SDG ultracentrifugation and the gradient fractions collected at $0^{\circ} \mathrm{C}$ into tubes chilled in an ice bath. The $16 \mathrm{~S}$ area of the gradient was pooled and frozen in aliquots at $-70^{\circ} \mathrm{C}$. Activation analyses were carried out by incubating experimental samples with reconstituted ${ }^{125} \mathrm{I}-\mathrm{Cl}$ s-labeled $\mathrm{Cl}$. Each aliquot contained $0.2-1.0 \mu \mathrm{g}$ of $\mathrm{Cl}$, and the total volume of the activation reaction mixture was 25-50 $\mu \mathrm{l}$. Negative controls lacking activator but containing urate-saturated buffer and positive controls containing $10 \mu \mathrm{g}$ of aggregated IgG or $5 \mu \mathrm{g}$ of lipopolysaccharide (strain R 595) (15) were routinely included. After incubation for $20 \mathrm{~min}$ at $30^{\circ} \mathrm{C}$, SDS, urea, and dithiothreitol were added and the mixtures analyzed by SDS-PAGE. Because all of the radiolabel appears in either the proenzyme 87,000 -dalton peak or the 59,000 -dalton peak of the heavy chain of $\mathrm{Cls}$, quantitation of $\mathrm{Cl}$ activation by the various activators was achieved by determining the percentage of total radioactivity transferred to the 59,000dalton peak of the heavy chain of $\overline{C 1 s}$, after correcting for spontaneous $\mathrm{Cls}$ activation in the sample containing uratesaturated buffer. Urate-saturated buffer alone did not activate $\mathrm{Cl}$ in comparison to the same buffer without dissolved urate.

\section{RESULTS}

Complement activation by urate crystals in serum. To determine the extent to which urate crystals would deplete serum complement, varying amounts of crystals were incubated in serum for $30 \mathrm{~min}$ at $37^{\circ} \mathrm{C}$. Hemolytic assays for $\mathrm{Cl}, \mathrm{C} 4, \mathrm{C} 3$, and $\mathrm{CH}_{50}$ were performed on the serum after the crystals had been removed by centrifugation. Complement depletion by $20 \mathrm{mg} / \mathrm{ml}$ of crystals in serum is shown in Fig. 1. The pattern of depletion observed, with proportionate reductions of $\mathrm{CH}_{50}$ and of $\mathrm{C} 1, \mathrm{C} 4$, and also $\mathrm{C} 3$ is indicative of classical pathway activation. As shown in the dose-response experiment depicted in Fig. 2, $\mathrm{CH}_{50}$, $\mathrm{Cl}$ and $\mathrm{C} 3$ activities were progressively depleted as the dose of crystals added to serum was increased. Thus, the $\mathrm{CH}_{50}, \mathrm{Cl}$, and $\mathrm{C} 3$ activities were reduced 57,52 , and $46 \%$, respectively, after incubation of serum with $10 \mathrm{mg} / \mathrm{ml}$ of crystals.

C1 binding by urate crystals. The reduction in $\mathrm{C} 1$ levels observed in the above studies (Figs. 1 and 2) suggested that $\mathrm{Cl}$ bound to urate crystals. To further evaluate this possibility, urate crystals were incubated for $10 \mathrm{~min}$ at $0^{\circ} \mathrm{C}$ with reconstituted macromolecular $\mathrm{Cl}$ that had been formed from highly purified immunoglobulin-free $\mathrm{Clq}$, proenzyme $\mathrm{Clr}$, and ${ }^{125}$ I-labeled proenzyme $\mathrm{C} 1 \mathrm{~s}$ during $10 \mathrm{~min}$ of incubation at $0^{\circ} \mathrm{C}$ in the presence of calcium as described (11). Cl binding was appraised and quantitated by sucrose density gradient ultracentrifugation. As shown in Table I, urate crystals bound macromolecular $\mathrm{C} 1$ in the absence of immunoglobulin. No binding of radiolabeled Cls occurred when $\mathrm{Clq}, \mathrm{Clr}$, and $\mathrm{Cls}$ were incubated with crystals in the presence of EDTA. Binding also did not occur when $\mathrm{Clq}$ was omitted from the mixtures.

C1 activation by urate crystals. Although the

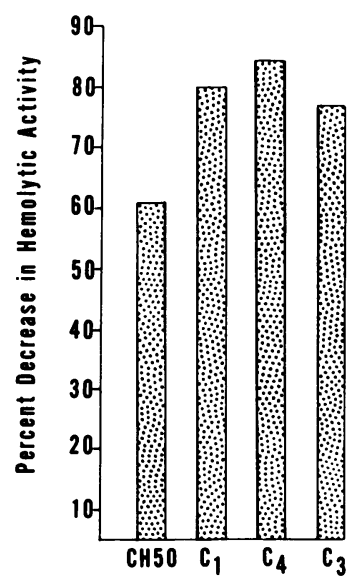

FIgURE 1 Percentage of decrease in complement activity of normal human serum after incubation $30 \mathrm{~min}$ at $37^{\circ} \mathrm{C}$ with $20 \mathrm{mg} / \mathrm{ml}$ urate crystals. 


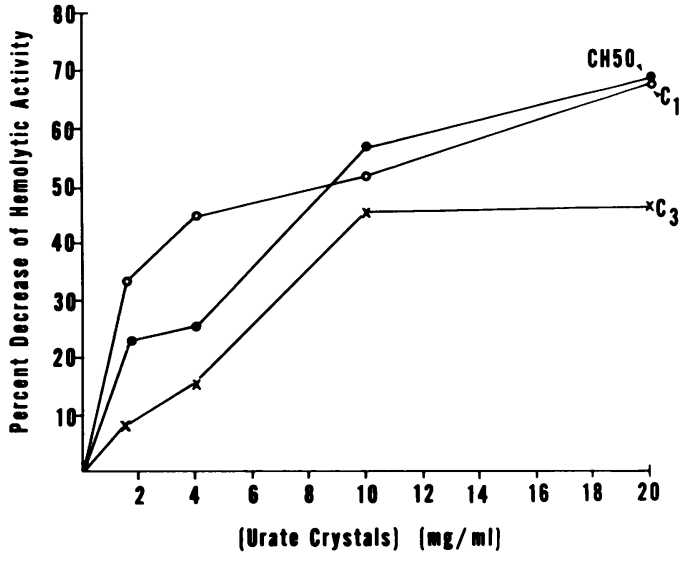

Figure 2 Percentage of decrease in $\mathrm{CH}_{50}, \mathrm{Cl}$, and $\mathrm{C} 3$ activities of normal human serum after $30 \mathrm{~min}$ at $37^{\circ} \mathrm{C}$ with increasing amounts of urate crystals.

above studies indicated that $\mathrm{Cl}$ could bind to urate crystals without the participation of immunoglobulin, it remained to be determined whether this interaction was productive and resulted in $\mathrm{Cl}$ activation. To investigate this question, urate crystals were incubated with macromolecular $\mathrm{Cl}$ reconstituted from purified immunoglobulin-free $\mathrm{Clq}$, proenzyme $\mathrm{Clr}$, and ${ }^{125} \mathrm{I}$ labeled proenzyme Cls. Activation was assessed by SDS-PAGE. As depicted in Fig. 3, urate crystals efficiently activated macromolecular $\mathrm{Cl}$. In similar experiments urate crystals produced no direct activation of $\mathrm{Cls}$ or $\mathrm{Clr}-\mathrm{Cl}$ s mixtures but did so on addition of $\mathrm{Clq}$, implying that integrity of the $\mathrm{Cl}$ macromolecule is required for activation. Dose-response studies showed that urate crystals activated $\mathrm{Cl}$ over a very wide dose range with the maximal activation achievable being $\cong 90 \%$ of that obtained with aggregated IgG. In five experiments, the average dose of urate crystals producing $50 \%$ of maximal activation of the $0.7 \mu \mathrm{g}$ of $\mathrm{Cl}$ in the test system was $2.7 \mu \mathrm{g}$. In addition, however, inhibition of $\mathrm{Cl}$ activation at high urate: $\mathrm{Cl}$ ratios, as shown in Fig. 4, was observed in each of the five studies of this type. Nevertheless, even at $120 \mu \mathrm{g}$ of urate crystals, binding studies identical to those described above showed that $\mathrm{Cl}$ was bound to the crystals. Thus, the inability of high urate doses to activate $\mathrm{Cl}$ was not because of failure of the crystals to bind $\mathrm{Cl}$.

Lack of participation of endotoxin in complement activation by monosodium urate crystals. The uric acid crystals were originally heated at $200^{\circ} \mathrm{C}$ before neutralization with $\mathrm{NaOH}$ to destroy possible pyrogens, and then frozen in small aliquots that were thawed once just before use. Several tests were performed to further rule out the participation of lipopolysaccharide in the complement activation observed in these results. The crystals were dissolved in sterile
TABLE I

C1 Binding by Urate Crystals

\begin{tabular}{cc}
\hline Dose of crystals* & Percentage $\mathrm{Cl}$ bound $t$ \\
\hline$\mu g$ & $\%$ \\
15 & 46 \\
3 & 16 \\
0.6 & 1 \\
\hline
\end{tabular}

Percentage of $\mathrm{Cl}$ bound by urate crystals after $10 \mathrm{~min}$ at $0^{\circ} \mathrm{C}$. * Amount of crystals incubated with $5 \mu \mathrm{g}$ of $\mathrm{Cl}$.

$\ddagger$ Corrected for background level of $17 \% \mathrm{Cl}$ pelleted in absence of crystals.

$\mathrm{NaCl}$ at $100^{\circ} \mathrm{C}$ at a concentration of $0.1 \mathrm{mg} / \mathrm{ml}$ and $50 \mathrm{ml}$ was infused intravenously into rabbits. Neither temperature elevation nor neutropenia resulted, indicating that the crystals contained $<50 \mathrm{ng}$ of bacterial lipopolysaccharide per $5 \mathrm{mg}$ of urate crystals (19). Also, bacteriologic cultures of the crystals were sterile.

In another approach, sodium urate crystals were heated at $200^{\circ} \mathrm{C}$ for $2 \mathrm{~h}$ to destroy potential pyrogens and then reexamined for complement activating ability. As shown in Table II, the ability of the heated crystals to activate the classical pathway in serum was somewhat decreased but not abolished.

Lack of IgG requirement for complement activation by urate crystals. To investigate a possible requirement for immunoglobulin for $\mathrm{Cl}$ activation by urate crystals, $\mathrm{Cl}$ activation assays were carried out in the presence of $F\left(a b^{\prime}\right)_{2}$ fragments of a goat anti-human $F_{c}$ antibody. As shown in Table III, the level of $\mathrm{F}\left(\mathrm{ab}^{\prime}\right)_{2}$

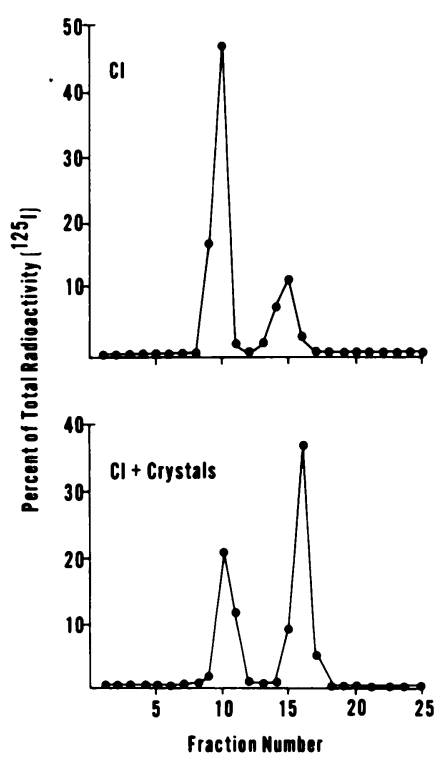

Figure 3 Activation of $\mathrm{Cl}$ as shown by shift in peak of ${ }^{125} \mathrm{I}$ $\mathrm{Cls}$ from proenzyme 87,000 dalton form to 59,000$)$ dalton activated C $\overline{1 s}$ form. Top of SDS-PAGE is at the origin, points represent percentage of total radioactivity of each $2-\mathrm{mm}$ slice. 




Figure 4 Activation of $\mathrm{Cl}$ urate crystals over a 100-fold dose range.

anti-Fc antibody used, $15 \mu \mathrm{g}$, completely blocked C1 activation by $10 \mu \mathrm{g}$ of aggregated human IgG. However, the $\mathrm{F}\left(\mathrm{ab}^{\prime}\right)_{2}$ anti-Fc antibody had no effect on the $\mathrm{Cl}$ activating ability of the urate crystals. Because of the biphasic relationship between the dose of urate crystals and $\mathrm{Cl}$ activation (Fig. 4), it was important to study the effect of $\left.F(a)^{\prime}\right)_{2}$ anti-Fc antibody on doses of crystals producing submaximal activation. As shown in Table III, in this experiment, $3 \mu \mathrm{g}$ of urate crystals produced only $33 \%$ of the maximal amount of $\mathrm{Cl}$ activation. 15 $\mu \mathrm{g} F\left(\mathrm{ab}^{\prime}\right)_{2}$ anti- $\mathrm{Fc}_{\mathrm{c}}$ antibody had no effect on $\mathrm{Cl}$ activation even at this low crystal dose. Thus, we conclude that $\operatorname{IgG}$ is not required for $\mathrm{Cl}$ activation by urate crystals.

\section{DISCUSSION}

These studies indicate that urate crystals can activate the classical pathway of complement when added to serum. In our experiments, $10 \mathrm{mg}$ urate crystals $/ \mathrm{ml}$ produced $57 \%$ reduction of $\mathrm{CH}_{50}$. For comparison, in experimental gout (20), crystal concentrations of $\cong 7.5$ $\mathrm{mg} / \mathrm{ml}$ induce inflammation in canine stifle joints. Although complement activation by urate crystals has been demonstrated $(3,4,21)$, and depression of $\mathrm{C} 4$, C2, and C3 levels was described (3), indicating classical pathway activation, the exact mechanism was not resolved. The marked depression of C4, C2, and C3 levels with little alteration in $\mathrm{Cl}$ titers observed by Naff and Byers (3) led them to postulate a novel mechanism of

TABLE II

Effect of Heating on the Ability of Urate Crystals to Activate Complement in Serum

\begin{tabular}{lccccc}
\hline & \multicolumn{4}{c}{$\begin{array}{c}\text { Percentage of reduction in } \\
\text { complement activity }\end{array}$} \\
\cline { 2 - 6 } & $\mathrm{CH}_{50}$ & $\mathrm{C} 1$ & $\mathrm{C} 4$ & $\mathrm{C} 3$ \\
\hline & \multicolumn{5}{c}{$\%$} \\
Urate crystals untreated & 90 & 94 & 98 & 87 \\
Urate crystals, $200^{\circ} \mathrm{C} \times 2 \mathrm{~h}$ & 63 & 81 & 88 & 75
\end{tabular}

Complement activation in normal human serum incubated $30 \mathrm{~min}$ at $37^{\circ} \mathrm{C}$ with $20 \mathrm{mg} / \mathrm{ml}$ untreated crystals or crystals heated at $200^{\circ} \mathrm{C}$ for $2 \mathrm{~h}$.
TABLE III

Lack of Requirement for IgG for C1 Activation by Urate Crystals

\begin{tabular}{cc}
\hline & $\begin{array}{c}\text { Percentage of } \\
\text { maximal C1 } \\
\text { activation }\end{array}$ \\
\hline Agg IgG, $10 \mu \mathrm{g}$ & $\%$ \\
$+15 \mu \mathrm{g} \mathrm{F}\left(\mathrm{ab}^{\prime}\right)_{2} \mathrm{Ab} \mathrm{Fc} *$ & 100 \\
Urate crystals, $10 \mu \mathrm{g}$ & 0 \\
$+15 \mu \mathrm{g} \mathrm{F}\left(\mathrm{ab}^{\prime}\right)_{2} \mathrm{Ab} \mathrm{Fc}$ & 92 \\
Urate crystals, $3 \mu \mathrm{g}$ & 92 \\
$+15 \mu \mathrm{g} \mathrm{F}\left(\mathrm{ab}^{\prime}\right)_{2} \mathrm{Ab} \mathrm{Fc}$ & 33 \\
\hline
\end{tabular}

Effect on $\mathrm{Cl}$ activation of adding goat $\mathrm{F}\left(\mathrm{ab}^{\prime}\right)_{2}$ anti-human IgG $\mathrm{Fc}$ to aggregated IgG or to urate crystals. * anti-Fc antibody.

complement activation. In addition the possible roles played by immunoglobulin and lipopolysaccharide in the observed complement activation have not been clarified.

The pattern of complement component consumption observed in our studies, with marked C1, C4, and C3 depletion is typical of classical pathway activation. We thus have no explanation for the failure of Naff and Byers (3) to observe a reduction in $\mathrm{C} 1$ levels proportionate to the reduction in $\mathrm{C} 4, \mathrm{C} 2$, and $\mathrm{C} 3$ levels. In addition, in our studies, urate crystals were found to directly activate isolated macromolecular $\mathrm{Cl}$, further indicating that urates can activate complement via $\mathrm{Cl}$. Furthermore, activation by urate crystals required intact macromolecular $\mathrm{Cl}$, as no $\mathrm{Cls}$ activation occurred when omitting $\mathrm{Clq}$ or $\mathrm{Clr}$ or both components. Thus, $\mathrm{Cl}$ activation by urate crystals does not involve direct activation of Clr or Cls by the crystals as observed with univalent 2,4-dinitrophenol-polylysine-antibody complexes (22) and certain enzymes such as plasmin (23). It is most likely, therefore, that urate crystals, like most activators, activate $\mathrm{Cl}$ via an initial interaction with $\mathrm{Clq}$ followed by sequential $\mathrm{Clr}$ and $\mathrm{Cls}$ activation. We thus find no evidence for another pathway of activation distinct from the classical and alternative pathways.

There has been some concern that possible bacterial lipopolysaccharide contamination of urate preparations might be involved in complement activation by urate crystals. Both Phelps and McCarty (21) and Naff and Byers (3) reported that urate crystals heated at $200^{\circ} \mathrm{C}$ for $2 \mathrm{~h}$, to destroy possible contaminating pyrogens, consumed less complement than unheated crystals. However, complement consuming activity was regained in Naff and Byers' studies (3) when the heated crystals were dissolved and reformed, providing evidence against lipopolysaccharide mediation of the complement consumption. In our studies, we also found that 
crystals heated at $200^{\circ} \mathrm{C}$ for $2 \mathrm{~h}$ could still activate the complement system in serum (Table II). Common contaminating bacterial lipopolysaccharides are smooth, polysaccharide-rich strains that predominantly activate the alternative pathway (24). Contamination with a lipid A-rich rough mutant that selectively activated the classical pathway (15) would be unusual. Measurable complement consumption in our studies was obtained with $16 \mu \mathrm{g}$ of urate crystals per milliliter of serum that could have contained at most $0.16 \mathrm{ng}$ of lipopolysaccharide per milliliter. This is several orders of magnitude less than the amount of lipopolysaccharide required to produce measurable classical pathway activation (15). Similarly, activation of purified Cl occurred with 3-10 $\mu \mathrm{g}$ of urate crystals that could have contained no $>0.03-0.1 \mathrm{ng}$ of lipopolysaccharide. However, $\mathrm{Cl}$ activation by lipid A or by lipid A-rich lipopolysaccharide preparations requires $100 \mathrm{ng}$ or more of this material (15). By similar argument, the $\mathrm{Cl}$ preparations themselves must have contained $<100$ ng lipid A-rich-lipopolysaccharide as they were unactivated. Taken together, these data rule out the possibility that lipopolysaccharide alone is responsible for complement activation by urate crystals.

Although not examined in detail, there appeared to be a reasonable relationship between $\mathrm{Cl}$ binding and $\mathrm{C} 1$ activation at lower crystal: $\mathrm{Cl}$ ratios. For example, $15 \mu \mathrm{g}$ of urate crystals bound $46 \%$ of the offered $5 \mu \mathrm{g}$ of $\mathrm{C} 1$, whereas $2.7 \mu \mathrm{g}$ of crystals produced $50 \%$ activation of $0.7 \mu \mathrm{g}$ of $\mathrm{Cl}$. However, at high doses of crystals, $\mathrm{Cl}$ activation was inhibited, although parallel binding studies showed that the $\mathrm{Cl}$ was bound. This same phenomenon of inhibition of activation at elevated doses has been previously observed with another activator (15). The reasons for this type of inhibition are not clear but are presumably related to steric effects.

Urate crystals avidly bind IgG (5) and are probably coated with immunoglobulin in vivo. Naff and Byers (3) showed that urate crystals could deplete complement activity in most immunoglobulin deficient sera. Our studies show that IgG is not necessary for efficient $\mathrm{Cl}$ activation by urate crystals. Not only did urate crystals bind and also activate immunoglobulin-free macromolecular $\mathrm{Cl}$, but $\mathrm{Cl}$ activation by urate crystals proceeded unimpaired in the presence of $F\left(a b^{\prime}\right)_{2}$ fragments of anti-human Fc antibody. In the same experiments, the $\mathrm{F}\left(\mathrm{ab}^{\prime}\right)_{2}$ anti-Fc completely blocked $\mathrm{Cl}$ activation by aggregated IgG.

The data presented in this paper have defined the mechanism by which monosodium urate crystals, the etiologic agent of gout, activate the complement system. Efficient immunoglobulin-independent activation of the classical pathway supports the hypothesis (3) that activation of complement directly contributes to the acute inflammatory response of gout.

\section{ACKNOWLEDGMENTS}

The authors would like to thank Susan Host, Kathy Altman, and Rick Landes for their expert technical assistance; Jonne Stephenson for typing the manuscript, and Michael Miller for the $x$-ray crystallography of the urate crystals.

This work was supported by U. S. Public Health Service grants GM-24834, AI-07007, CA-14692, 1 SO7-RR05514, and HL-16411.

\section{REFERENCES}

1. Webster, M. E., H. M. Maling, M. H. Zweig, M. A. Williams, and W. Anderson, Jr. 1972. Urate crystal induced inflammation in the rat: evidence for the combined actions of kinins, histamine and complement. Immunol. Commun. 1: 185-198.

2. Kellerman, R. W., and G. B. Naff. 1975. Chemical mediators of inflammation in acute gouty arthritis. Arthritis. Rheum. 18(Suppl.): 765-770.

3. Naff, G. B., and P. H. Byers. 1973. Complement as a mediator of inflammation in acute gouty arthritis. I. Studies on the reaction between human serum complement and sodium urate crystals. J. Lab. Clin: Med. 81: 747-760.

4. Byers, P. H., P. A. Ward, R. W. Kellermeyer, and G. B. Naff. 1973. Complement as a mediator of inflammation in acute gouty arthritis. II. Biological activities generated from complement by the interaction of serum complement and sodium urate crystals. J. Lab. Clin. Med. 81: 761-769.

5. Kozin, F., and D. J. McCarty. 1977. Protein binding to monosodium urate monohydrate, calcium pyrophosphate dihydrate and silicon dioxide crystals. I. Physical characteristics. J. Lab. Clin. Med. 89: 1314-1325.

6. Ginsberg, M. H., F. Kozin, M. O'Malley, and D. J. McCarty. 1977. Release of platelet constituents by monosodium urate crystals. J. Clin. Invest. 60: 999-1007.

7. Howell, R. R., E. D. Eanes, and J. E. Seegmiller. 1963. Xray diffraction studies of the tophacious deposits in gout. Arthritis Rheum. 6: 97-103.

8. Yonemasu, K., and R. M. Stroud. 1971. Clq: rapid purification method for preparation of monospecific antisera and for biochemical studies. J. Immunol. 106: 304-313.

9. Ziccardi, R. J., and N. R. Cooper. 1976. Physicochemical and functional characterization of the Clr subunit of the first complement component. J. Immunol. 116: 496-503.

10. Valet, G., and N. R. Cooper. 1974. Isolation and characterization of the proenzyme form of the $\mathrm{Cl}$ s subunit of the first component of complement. J. Immunol. 112: 339-350.

11. Cooper, N. R., and R. J. Ziccardi. 1977. Reconstitution of $\mathrm{Cl}$ in native proenzyme form and its use in a quantitative Ci activation test. J. Immunol. 119: 1664-1667.

12. Ginsberg, M. H., and F. Kozin. 1978. Mechanisms of cellular interaction with monosodium urate crystals: IgGdependent and IgG-independent platelet stimulation. Arthritis Rheum. 21: 896-903.

13. Weber, K., and M. Osborne. 1969. The reliability of molecular weight determinations by dodecyl sulfate-polyacrylamide gel electrophoresis.J. Biol. Chem. 244: 4406-4412.

14. Mayer, M. M. In Experimental Immunochemistry. E. A. Kabat and M. M. Mayer, editors. C. C. Thomas, Springfield, Illinois. $133 \mathrm{pp}$.

15. Cooper, N. R., and D. C. Morrison. 1978. Binding and activation of the first component of human complement by the lipid-A region of lipopolysaccharides. J. Immunol. 120: $1862-1868$.

16. Rapp, H. J., and T. Borsos. 1970. The Molecular Basis of Complement Action. Appleton-Century-Crofts, New York. 97-109.

17. Gaither, T. A., D. W. Alling, and M. M. Frank. 1974. A new 
one-step method for the functional assay of the fourth component of human complement. J. Immunol. 113: $574-583$

18. Cooper, N. R., and R. J. Ziccardi. 1978. Reconstitution of $\mathrm{Cl}$ in native proenzyme form and analysis of the $\mathrm{Cl}$ activation process. J. Immunol. 120: 1768. (Abstr.)

19. Ulevitch, R. J., and A. R. Johnston. 1978. The modification of biophysical and endotoxic properties of bacterial lipopolysaccharides by serum. J. Clin. Invest. 62: 1313-1324.

20. McCarty, D. J., P. Phelps, and J. Pyonson. 1966. Crystal induced inflammation in canine joints. An experimental model with quantification of the host response. J. Exp. Med. 124: 99-114.
21. Phelps, P., and D. J. McCarty. 1966. Crystal-induced inflammation in canine joints. II. Importance of polymorphonuclear leukocytes. J. Exp. Med. 124: 115-125.

22. Goers, J. W., R. J. Ziccardi, V. N. Schumaker, and M. Michael Glovsky. 1977. The mechanism of activation of the first component of complement by a univalent haptenIgG antibody complex. J. Immunol. 118: 2181-2191.

23. Ratnoff, O. D., and G. B. Naff. 1967. The conversion of C1s to $\mathrm{Cl}$ esterase by plasmin and trypsin. J. Exp. Med. 125: $337-358$.

24. Bladen, H. A., H. Gerwurz, and S. E. Mergenhagen. 1966. Interactions of the complement system with the surface and endotoxic lipopolysaccharide of Veillonella alcalescens. J. Exp. Med. 125: 767-786. 